\title{
First occurrence of Leightoniomyces phillipsii (Berk. \& Leight.) D. Hawksw. \& B. Sutton for South America
}

\author{
ROSELY ANA PICCOLO GRANDI ${ }^{1,2}$
}

(received: June 13, 2012; accepted: August 09, 2012)

\begin{abstract}
First occurrence of Leightoniomyces phillipsii (Berk. \& Leight.) D. Hawksw. \& B. Sutton for South America). Leightoniomyces phillipsii (Berk. \& Leight.) D. Hawksw. \& B. Sutton, an anamorphic fungus, is described and illustrated for the first time for South America. This synnematous fungus with typical coarsely verrucose conidia was previously known to be associated only with lichens, but can be associated with plant roots. This discovery extends its habitat, geographical distribution, and ecosystem roles.
\end{abstract}

Key words - anamorphic fungi, hyphomycetes, soil fungi, synnematous fungi

\section{INTRODUCTION}

The anamorphic fungus genus Leightoniomyces D. Hawksw. \& B. Sutton was proposed in 1977 as associated with the lichens Thrombium epigaeum (Pers.) Wallr. and Steinia geophana (Nyl.) Stein (Hawksworth 1977). The type species L. phillipsii (Berk. \& Leight.) D. Hawksw. $\&$ B. Sutton was described as a new combination from Periconia phillipsii Berk. \& Leight., and five synonyms were indicated by Hawksworth (1977) and two by McCune \& Stone (2009). The genus is currently accepted and remains monotypic (Seifert et al. 2011, Kirk 2012).

Collections and a historical review of this fungus were presented by Hawksworth (1977) who cited its first collection in 1874 by Leighton in England, the second in 1975 by P.W. James also in England, and the third in 1977 by P.W. James on the Azores Islands, Portugal. The taxon was rediscovered in 2009 by B. McCune in soil collections from Oregon, USA, and that description was the first for North America (McCune \& Stone 2009). This species was known only in the Northern Hemisphere from temperate climate zones.

During examinations of the permanent slide collection of the SP Herbarium while confirming the identifications of conidial fungi found on roots and in leaf litter collected in São Paulo State, Brazil, a specimen slide of Leightoniomyces sp. was encountered, confirming that $L$. phillipsii had been collected in that country in 1989 . Other slides of the same material that

\footnotetext{
1. Instituto de Botânica, Núcleo de Pesquisa em Micologia, Caixa Postal 68041, 04045-972 São Paulo, SP, Brazil.

2. Corresponding author: rapgrandi@uol.com.br
}

had been stored for many years in the laboratory were identified and incorporated into the SP herbarium. The description presented here is the first for South America and represents a new habitat for this fungus.

\section{MATERIAL AND METHODS}

Collections were made in the Paranapiacaba Biological Reserve (Reserva Biológica de Paranapiacaba), Santo

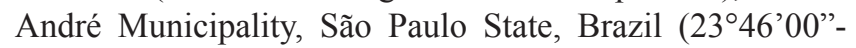
$23^{\circ} 47^{\prime} 10^{\prime \prime} \mathrm{S}$ and $46^{\circ} 18^{\prime} 20^{\prime \prime}-46^{\circ} 20^{\prime} 40^{\prime \prime} \mathrm{W}$ ), in April, July, September, and November/1989, April/1990, August/1995, and February/1996. Roots of Calathea zebrina (Sims) Lindl and Euterpe edulis Mart. were collected from 10-20 cm tall seedlings and their exposed rhizosphere and portions of their roots were removed. The root fragments were washed several times in the laboratory and subsequently maintained in moist chambers, according to Harley \& Waid (1955). The fungal structures to be identified were placed directly on slides with lactofenol cotton-blue or polyvinyl alcohol resin mounting medium (Kirk et al. 2008). Permanent slides were deposited in the SP Herbarium at the Instituto de Botânica, São Paulo State, Brazil.

\section{RESULTS}

Leightoniomyces phillipsii (Berk. \& Leight.) D. Hawks. $\&$ B. Sutton, Botanical Journal of the Linnean Society 75:200, 1977. $\equiv$ Periconia phillipsii Berk. \& Leight., Annals and Magazine of Natural History (series IV) 15:33, 1875.

Figures 1-4

Mycelium immersed in the substrate, with branched, septate, light brown to brown hyphae, $2-5 \mu \mathrm{m}$ wide. 
Conidiomata synnematous, superficial. Synnemata erect, rigid, subulate, indeterminate, with compact parallel hyphae, broad or bulbous bases, with fertile apical zone, brown or dark-brown, 135-575 $\mu \mathrm{m}$ tall and 15-45(-80) $\mu \mathrm{m}$ wide at base, $7.5-17.5(-20) \mu \mathrm{m}$ wide at the apex. Apical portion globose or sub-globose, with conidiogenous cells and compact dark-brown masses of conidia. Conidiophores adpressed, septate, smooth, branched in the upper part to form conidiogenous cells, brown, 2-3 $\mu \mathrm{m}$ wide. Conidiogenous cells holoblastic, cylindrical, flask-shaped, ampuliform or lageniform, integrated, terminal, annellidic with percurrent proliferatons, smooth, crowded at the apices of the synnemata, light-brown or hyaline, 7.7-12.5 $\times 4.5$ $7.5 \mu \mathrm{m}$. Conidia globose, non-septate, coarsely verrucose, dry, produced singly but adhering in chains by a connective, light-brown, $8-15 \mu \mathrm{m}$ in diameter, without verrucae; ornamentations raised and angular, dark-brown, 2-2.5 $\mu \mathrm{m}$ tall. Secession schizolytic.

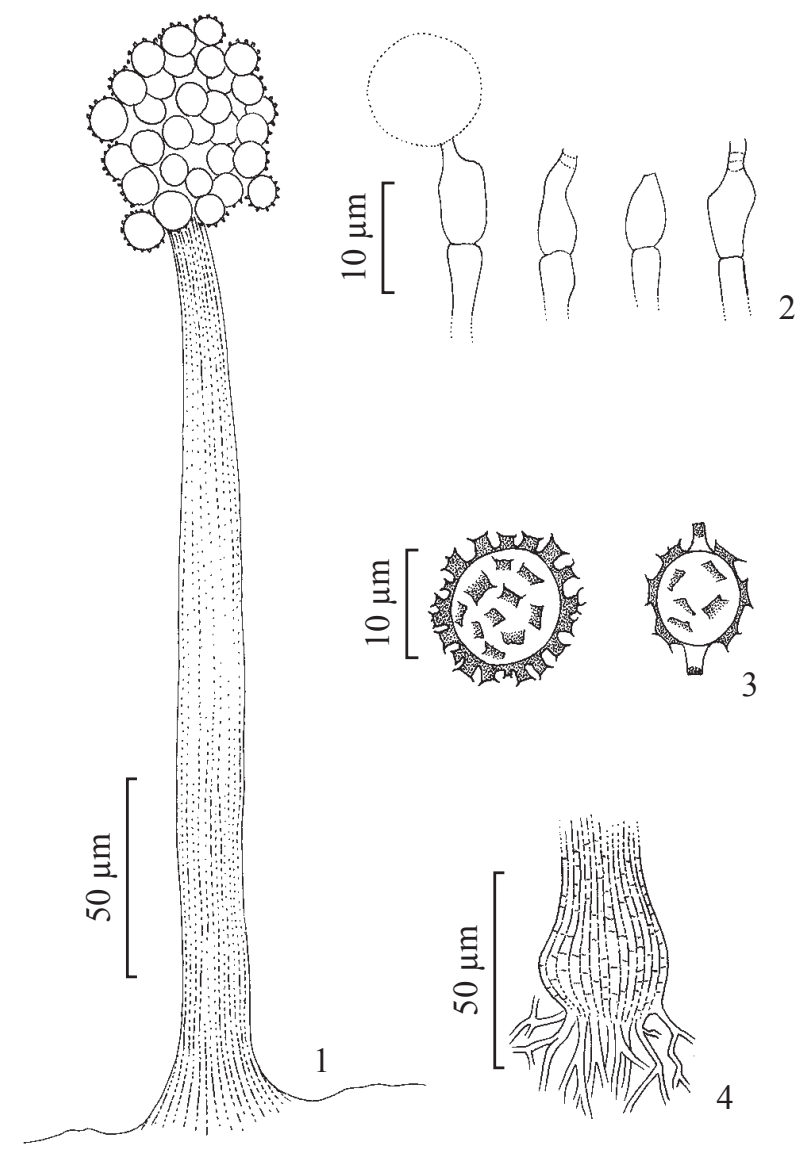

Figures 1-4. Leightoniomyces phillipsii. 1. Habit of a synnema. 2. Conidiogenous annellidic cells. 3. Conidia with angular verrucae, one of them with connectives. 4 . Bulbous base of a synnema, with vertically oriented hyphae.
Specimens examined: BRAZIL. São PaUlo: Santo André, Paranapiacaba Biological Reserve, Atlantic Rain Forest, on decomposing roots of Calathea zebrina (Sims) Lindl, 09-XI-1989, RAP Grandi s.n. (SP233781); idem, on decomposing roots of Euterpe edulis Mart., IV-1989, RAP Grandi s.n. (SP417367); idem, 25-VII1989, RAP Grandi s.n. (SP417368); idem, 28-IX-1989, RAP Grandi s.n. (SP417369); idem, 11-IV-1990, RAP Grandi s.n. (SP417370); idem, 01-VIII-1995, RAP Grandi s.n. (SP417371); idem, 01-VIII-1995, RAP Grandi s.n. (SP417372); idem, 01-VIII-1995, RAP Grandi s.n. (SP417373); idem, 05-II-1996, RAP Grandi s.n. (SP417374); idem, 05-II-1996, RAP Grandi s.n. (SP417375).

Geographical distribution: BRAZIL, São Paulo State (this paper); ENGLAND, Herefordshire (Hawksworth 1977); PORTUGAL, Azores (Hawksworth 1977, not Spain as published); UNITED STATES OF AMERICA, Oregon (McCune \& Stone (2009).

Habitat and ecosystem roles: soil, rhizosphere, roots of Calathea zebrina, roots of Euterpe edulis, associated with lichens; saprobic or endophytic.

\section{DISCUSSION}

The Brazilian materials agree with the original description (Hawksworth 1977), but differ in some aspects probably not seen at that time. The synnemata can be longer than $250 \mu \mathrm{m}$, as originally described, because the taxon has indeterminate synnemata. The conidiogenous cells were light-brown or hyaline and smooth not brown and rough-walled; they are delicate structures that can lose their round shape and become deformed. The conidia were described as not catenate (Hawksworth 1977, Muntañola-Cvetkovic \& GómezBolea 1998) but short chains of conidia were seen, with their connectives, in accordance with McCune \& Stone (2009) and the generic characterization by Seifert et al. (2011). Additionally, dark-brown or almost black conidia were mentioned by Hawksworth (1977) and McCune \& Stone (2009), but the conidia were lightbrown in all of the Brazilian specimens examined. The typical and conspicuous verrucae on the conidia walls were angular, brown or dark-brown, and the conidia formed a dark-brown mass. Illustrations of this fungus can be seen in Ellis (1971 as Doratomyces phillipsii (Berk. \& Leight.) Morton \& Smith, a synonym), Hawksworth (1977), McCune \& Stone (2009), and Seifert et al. (2011).

Hawksworth $(1977,1983)$ established this taxon as algicolous or lichenicolous, and $\mathrm{McCune} \&$ Stone 
(2009) found this species associated with the lichens Cladonia spp., Fuscopannaria sp., Leptogium sp., and Peltigera spp. However, soil particles were seen in all of the collections and were illustrated by McCune \& Stone (2009); Doratomyces phillipsii, its synonym, is a soil-inhabiting fungi (Ellis 1971).

Leightoniomyces phillipsii was isolated from the decomposing roots of Calathea zebrina (Marantaceae) and Euterpe edulis (Arecaceae) in the Atlantic Rain Forest and in wet habitats. It clearly occurs in the soil or rhizosphere as it has often been isolated from E. edulis. There have also been confirmed in cases in which only this fungus was associated with the plant roots. The technique employed is used to obtain decomposer or endophytic fungi from root surfaces in the soil (Harley $\&$ Waid 1955), and its discovery therefore extends the habitat and roles of L. phillipsii in soil ecosystems.

\section{REFERENCES}

Ellis MB. 1971. Dematiaceous Hyphomycetes. Commonwealth Mycological Institute, Surrey.
Harley JL. Waid JS. 1955. A method of studying active mycelia on living roots and other surfaces in the soil. Transactions of the British Mycological Society 38: 104-118.

Hawksworth DL. 1977. Three new genera of lichenicolous fungi. Botanical Journal of the Linnean Society 75: 195-209.

Hawksworth DL. 1983. A key to the lichen-forming, parasitic, parasymbiotic and saprophytic fungi occurring on lichens in the British Isles. Lichenologist 15:1-44.

Kirk P. 2012. Index Fungorum. http://www.indexfungorum. org/Names/Names.asp (accessed 2012 Apr 23).

Kirk PM, Cannon PF, Minter DW, Stalpers JA. 2008. Dictionary of the Fungi. 10th ed., CAB International, Wallingford.

McCune B, Stone J. 2009. Leightoniomyces phillipsii, a synnematous soil-dwelling hyphomycete new to North America. North American Fungi 4:1-4.

Muntañola-Cvetkovic M, Gómez-Bolea A. 1998. Arborillus llimonae nov. gen. et sp., a synnematous lichenicolous hyphomycete. Mycotaxon 68:145-155.

Seifert K, Morgan-Jones G, Gams W, Kendrick B. 2011. The genera of Hyphomycetes. CBS-KNAW Fungal Biodiversity Centre, Utrecht. 
